DOI: https://doi.org/10.32838/2523-4803/70-1-26

УДК 519.86

Богуславська С.I.

кандидат економічних наук, доцент,

доцент кафедри менеджменту та економічної безпеки,

Черкаський національний університет імені Б. Хмельницького

Стуглик Дюсоанна

кандидат економічних наук,

здобувач кафедри економіки, підприємництва та природничих наук,

Таврійський національний університет імені В.І. Вернадського

\title{
Boguslavskaya Svitlana
}

Cherkasy National Khmelnytsky University

Stuglik Dzhoanna

V.I. Vernadsky Taurida National University

\section{РОЛЬ РЕСУРСНОГО ЗАБЕЗПЕЧЕННЯ В ПРОГНОЗУВАННІ СОЦІАЛЬНО-ЕКОНОМІЧНОГО РОЗВИТКУ РЕГІОНУ}

У статті досліджено роль ресурсного забезпечення в прогнозуванні соціально-економічного розвитку регіону. Визначено, щзо прогнозування сочіально-економічного розвитку регіону є процесом із формування наукового обтрунтованого судження про можливий стан досліджуваних об'єктів. У роботі досліджено функиії управління сочіально-економічними процесами та проаналізовано місие $і$ роль прогнозування у даному процесі. Розглянуто підходи, які дають уявлення про предметну сферу регіонального сочіально-економічного прогнозування. На основі всебічного аналізу теорій регіонального розвитку, а також концепиій формування і використання ресурсів регіону надано авторське визначення ресурсного забезпечення соціально-економічного розвитку регіону. Доведено, щзо від ресурсного забезпечення регіону залежить розвиток багатьох сфер його життя, на основі иих даних будується управління територією, розробляються иільові програми, стратегії, від них якоюсь мірою залежать безпека населення і еволючія економічного сектору, тому в статті побудована структурна схема, яка відображає ресурсне забезпечення соиіально-економічного розвитку регіону.

Ключові слова: регіон, ресурсне забезпечення, прогнозування, сочіально-економічний розвиток, регіональне управління.

Постановка проблеми. Система регіонального управління процесами соціально-економічного зростання неможлива без прогнозування, що грає провідну роль сполучної ланки серед інших важливих елементів які реалізують підготовку відповідних рішень. Для регіональної системи помилитися у виборі управлінських рішень означає стати приводом для деградації іiі розвитку. Для нівелювання таких наслідків потрібно вилучити частину ресурсів, які забезпечують економічний розвиток і соціальне забезпечення громадян у регіоні.

Прогнозування $є$ процесом із формування наукового обгрунтованого судження про можливий стан досліджуваних об'єктів (об'єкта) в перспективі або ж інших способів в іншому часовому проміжку їх досягнення. Економічне прогнозування - це частина економічної прогностики, де досліджуються специфічні методи і підходи.

Аналіз останніх досліджень і публікацій. Багатоаспектність даної проблеми потребує вивчення великого кола спеціальної наукової літератури. Забезпе- ченість ресурсами, проблематика їх територіального розміщення та ефективності використання $\epsilon$ основою важливих економічних процесів та визначають напрям теоретико-методичних досліджень багатьох учених. Концептуальні основи формування та прогнозування ресурсного забезпечення регіонального господарського комплексу найкраще описані в роботах Г. Атаманчука, Н. Глазунової, В. Козбаненка, Л. Приходченка, О. Сушинського, Р. Абдеєва, О. Кірєєвої, О. Скаленка, А. Урсула, І. Юзвішіна та ін.

Формулювання цілей статті. Метою статті $\epsilon$ дослідження ролі ресурсного забезпечення в прогнозуванні соціально-економічного розвитку регіону.

Виклад основного матеріалу. Найчастіше прогнозування розглядається як компонента ще однієї сфери знання - управління, оскільки виходить із принципу «керуючи - передбачаю». Таким чином, поняття, закладені в теорію управління суспільними процесами, свідчать про те, що прогнозування займає провідне становище в регіональній системі управління процесами соціального та економічного розвитку й 
являє собою сполучний елемент серед реально необхідних і важливих функцій розроблення та реалізації належних рішень.

Підготовчий блок несе в собі функції, які мають аналітичний і дослідницький характер: 1. Інформація. Отримання на відповідному рівні моніторингу актуальних аналітичних і статистичних відомостей про динаміку і характер соціально-економічних процесів i знайомство 3 новітніми тенденціями та досвідом у цій сфері. Етап супроводжується збором усієї вторинної інформації з питань, які потребують розгляду. 2. Цілепокладання. Орієнтуючись на загальну соціальну мету, підвищення якості життя населення та забезпечення безпеки і соціальних гарантій, розроблення векторної системи конкретних напрямів соціально-економічного розвитку стосовно заданого інтервалу часу. 3. Аналіз. Розгляд інформації, що надійшла, про динаміку і характер соціально-економічних процесів, зіставлення iii з необхідними індикаторами й узагальнення даних. 4. Вимірювання. Створення системи соціально-економічних індикаторів, що включають методи їх кількісної оцінки, а також удосконалення даної системи. 5. Діагностика. Виявлення позитивних і негативних чинників, що позначилися на стані й рівні соціально-економічного розвитку, підготовка загального висновку. 6. Прогнозування. Процес, пов'язаний $з$ обгрунтуванням різних варіантів розвитку соціальної та/або економічної ситуації з їх наслідками, що не виключають вплив зовнішніх і внутрішніх чинників.

Підготовчий блок завершується прогнозуванням, але процес, пов'язаний із ним, не припиняється, оскільки він є основою реалізації виконавчого блоку, що передбачає програмно-управлінський характер. Розглянемо їх коротко: 1. Програмування. Формування соціально-економічних програм розвитку регіону. 2. Планування. Розроблення планів, передбачених програмою. 3. Координація між учасниками програм, оперативне та ефективне узгодження діяльності. 4. Мотивація. Заходи для учасників програми, спрямовані на зростання у них інтересу. 5. Контроль. Хід виконання програми і його моніторинг. 6. Регулювання. Внесення директив у хід виконання програми.

Виконавчий блок із визначеними функціями - це показник якості й ефективності розроблених прогнозів регіонального соціально-економічного розвитку.

Органи державної влади на будь-якому рівні, консалтингові, науково-дослідні корпорації підприємства й організації, окремі експерти можуть виступати в ролі суб'єктів прогнозування соціально-економічного розвитку.

Об'єктами такого прогнозування виступають події, процеси й явища, що відображають практичну і пізнавальну діяльність суб'єктів прогнозування, що використовує системи демографічних, соціальних та економічних, показників, у тому числі значення чинників, що впливають на ці показники.

Соціально-економічний розвиток регіону виступає як предметна сфера, дає можливість говорити про специфічності об'єкта і суб'єктів, характерні для соціально-економічного прогнозування. Для опису аналізованої предметної сфери існують різні підходи. Доцільно перед описом предметної сфери прогнозування соціально-економічних процесів описати структуру соціальної сфери регіону та його економіки.

Розглянемо три підходи, які дають уявлення про предметну сферу регіонального соціально-економічного прогнозування.

Думка про те, що регіон, розвиваючись, намагається реалізувати економічні, інституційні, соціальні, екологічні та етнопсихологічні функції, лежить в основі першого підходу.

Питаннями опису предметної сфери регіонального прогнозування в регіоні займається другий підхід, де виділено його рівні: відтворювальний, фінансовий, соціальний; виробничий блок по праву займає центральну позицію його інтересів. Прогнозування і моделювання тут грунтується на різних підходах, для різних об'єктів і тимчасових інтервалів. Предметом аналізу виступають показники, що відображають стан матеріального середовища, розвиток і зміну яких важливо відстежити в просторі й часі. Ключове місце займають аналіз і прогноз демографічних показників, трудових ресурсів, заснований на розвитку території та спеціальних методах прогнозування.

Банківські та фіскальні служби становлять фінансово-кредитну оболонку, тут піддаються аналізу такі показники: величина банківських відсотків, ставка рефінансування, показник бюджетних доходів, оцінка прогнозу ризику взаємодії.

Соціальна оболонка. Моделювання і прогнозування знаходяться у тісному взаємозв'язку з такими соціальними об'єктами, як освіта, культура, наука й охорона здоров'я, спорт та ін. Такі прогнози, що носять предметний характер, входитимуть до сфери діяльності спеціалістів, які займаються конкретною предметною сферою. Незважаючи на деяку специфічність, цілий набір показників, що мають соціальний характер, тісно пов'язаний із попередніми блоками i буде особливо цікавий під час складання регіонального прогнозу розвитку. До числа таких показників можна віднести дохід і рівень життя, соціальний захист, зайнятість та безробіття тощо.

Збільшення відстані від виробничого ядра до інших оболонок призводить до утруднення роботи методів прогнозу, через що з'являються між запропонованими сферами взаємодій. У даному разі управлінцю можуть допомогти експертні підходи.

Третій підхід дає можливість описувати об'єкти, що належать до соціально-економічного прогнозування регіону, і застосовує галузеву структуру соціальноекономічної системи. Більш важливими для прогнозування будуть галузі промисловості, будівництва, сільського господарства, транспорту і зв'язку, торгівлі та громадського харчування, охорони здоров'я, освіти, науки й наукового обслуговування, культури та мистецтва. Необхідно відзначити, що всі галузі будуть 
входити в дві групи - соціальну сферу і матеріальне виробництво. Найважливіші з галузей матеріального виробництва поділяться на підгалузі.

Методологія прогнозування соціально-економічної системи країни визначає методологію регіонального прогнозування економічного і соціального розвитку, та навпаки.

Розвиток статистики визначає iii взаємозв'язок iз практикою прогнозування i планування, цей взаємозв'язок простежується на всьому переході до ринкової економіки. Дані, отримані з економічної статистики, дають можливість систематично кількісно описувати всі основні аспекти економіки та здійснювати постійний контроль над змінами, що відбуваються. Науково обгрунтований комплекс методів i принципів щодо формування та структурування статистичної інформації $є$ методологічним базисом статистичних досліджень.

Інтереси аналізу регіональної економіки не можуть бути повною мірою задоволені існуючою сьогодні структурою державної статистики. Тіньова економіка досі не втратила своєї актуальності й являє собою істотну проблему. Зростання обсягів тіньової економіки негативно позначається на розвитку регіону. Стають неможливими розроблення прогнозу та оцінка економічної ситуації в регіоні, не враховуючи тіньову економіку.

Необхідним стає створення інформаційно-координаційного центру колективного користування в регіоні. Особливістю такого центру має стати зміст інформації про інформацію. Також у кожному регіоні повинна бути розроблена правова база, яка регламентує процедури створення і використання даних. Зокрема, інформація про звітність підприємства і про його фінансову діяльність, надходячи до органів статистики для реалізації принципу одноразового збору і введення, повинна узгоджуватися з податковими органами. Структура паспортів підприємств, банків або ж регіону повинна бути взаємопогодженою і відповідати необхідним умовам сучасного управління.

Урізана структура паспорта регіону повинна містити такі розділи інформації: природно-ресурсний потенціал, трудові ресурси та їх використання, міжрегіональні та зовнішньоекономічні зв'язки, інвестиційний клімат та інвестиції, виробнича, ринкова, інформаційна інфраструктура, результати екологічного розвитку, результати соціального і демографічного розвитку.

Системна тріада «наявний потенціал - реалізований потенціал - кінцевий підсумок» повинна лягти в основу побудови регіонального інформаційного паспорта.

Верифікація прогнозу є важливим питанням, що випливає з проблем регіонального та інформаційного забезпечення прогнозної діяльності. Сучасні вчені трактують верифікацію як оцінку обгрунтованості прогнозу. У таку обгрунтованість найчастіше вкладають міру достовірності, точність прогнозу.
Адекватність передбаченого результату щодо реального значення досліджуваного процесу дає оцінку точності прогнозу. Передбачене і реальне значення, а також ступінь його близькості можна визначити після завершення прогнозного періоду, коли відомі реальні характеристики системи; у разі ретроспективного розроблення прогнозу, тобто маючи відомі фактичні дані.

Регіон являє собою систему, що динамічно розвивається та проходить певні етапи свого розвитку i може бути ототожнений із живим організмом, де природно-ресурсна база являє собою його генетичну основу, інфраструктура і зв'язок, його фізичний розвиток, а інноваційний сектор економіки відповідає його інтелекту. Усе це дає змогу полегшити класифікацію регіонів за різними виробничо-економічними чинниками і досліджувати проблеми, що виникають із цієї живої системи.

Життєдіяльність і конкурентоспроможність регіону багато в чому залежать від ресурсного забезпечення, що зумовлює необхідність чіткого контролю, а також своєчасного діагностування проблем, пов'язаних із нераціональним використанням ресурсів, їх виснаженням або загрозами, що виникають у зовнішньому середовищі і впливають на їх експлуатацію. Виходячи із цього, логічно зазначити, що якісна оцінка ресурсного забезпечення соціально-економічного розвитку регіону та іï фіксація в інформаційному полі з метою подальшого оперативного і раціонального використання є запорукою ефективного управління ситуацією.

У працях відомих економістів поняття ресурсного забезпечення соціально-економічного розвитку регіону ринковий аспект відображений недостатньо для сучасних умов, тому ми пропонуємо сформулювати його чіткіше, що дасть змогу встановити важливість управлінських чинників у взаємозв'язку між об'єктами управління в регіоні.

Грунтуючись на всебічному аналізі теорій регіонального розвитку, а також концепцій формування i використання ресурсів регіону, нами уточнене поняття ресурсного забезпечення соціально-економічного розвитку регіону. Дане поняття визначається нами як складна економічна категорія, інтегруюча сукупність ресурсів території, будучи в умовах ринкової економіки, знаходиться у взаємозалежності з внутрішніми i зовнішніми соціально-економічними, екологічними й управлінськими чинниками і тим самим визначає розвиток регіону. Дане трактування відрізняється від традиційних тим, що враховується не тільки сам ресурсний потенціал, а й управлінські чинники. Від ресурсного забезпечення регіону залежить розвиток багатьох сфер його життя, на основі цих даних будується управління територією, розробляються цільові програми, стратегії, від них якоюсь мірою залежать безпека населення й еволюція економічного сектору. Структурна схема, що відображає ресурсне забезпечення соціально-економічного розвитку регіону, відображена на рис 1.

Висновки. Ресурсне забезпечення соціально-економічного розвитку регіону як система потребує чіткого 


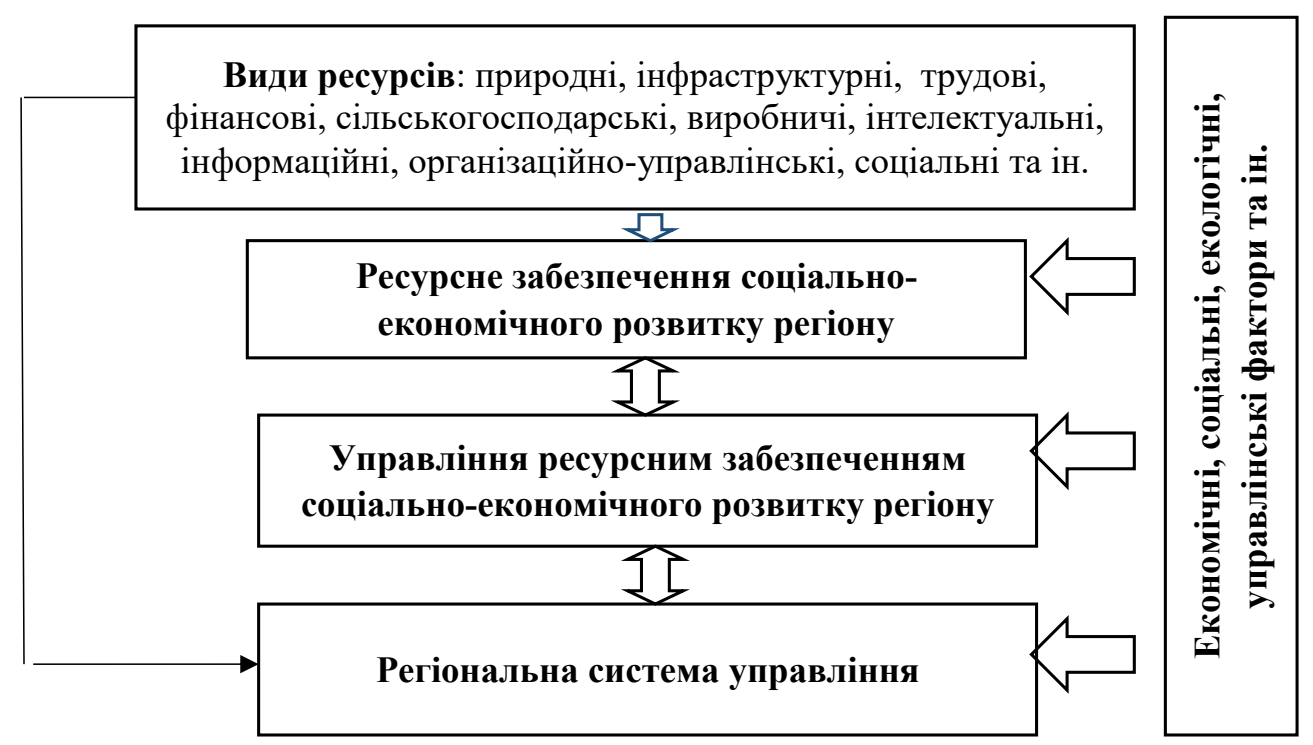

Рис. 1 Структурна схема ресурсного забезпечення соціально-економічного розвитку регіону

управління. Під управлінням ресурсним забезпеченням соціально-економічного розвитку регіону розуміється цілеспрямований вплив органів влади на економічні й соціальні відносини, що виникають у процесі використання можливостей території, що призводить тією чи іншою мірою до поліпшення регіональної економічної ситуації. Для грамотного управління необхідно встановити ті галузі дослідження, які будуть ураховуватися, контролюватися та увійдуть до складу регіональних інформаційних баз.

Для найбільш точного прогнозу необхідною умовою є отримання достовірної інформації про регіон, яка буде пов'язана безпосередньо 3 інформаційним забезпеченням оцінки ресурсного забезпечення соціально-економічного розвитку регіону.

Таким чином, інформаційна забезпеченість оцінки ресурсного забезпечення соціально-економічного розвитку регіону - це сукупність взаємопов'язаних елементів, що включають інформаційні електронні бази та інші інформаційні ресурси, які містять у собі інформацію про економічно важливі регіональні об'єкти, а також дають змогу систематизувати, обробляти й доповнювати дані відповідно до потреб політики регіону і його системи управління.

\section{Список літератури:}

1. Безверхнюк Т. Ресурсний режим як інституційний механізм ресурсного забезпечення регіонального управління. Державне будівництво. 2010. № 1. URL : http://www.kbuapa.kharkov.ua (дата звернення: 12.11.2019).

2. Крайник О.П. Особливості сучасних підходів до управління регіональним економічним розвитком. Ефективність державного управління. 2014. Вип. 39. С. 413-419.

3. Підлісна О.А. Стан та перспективи розвитку регіонів України: методи оцінки ефективності територіальних утворень. Регіональна економіка. 2007. № 1(43). С. 104-116.

4. Ресурсне забезпечення системи регіонального управління : наукова розробка / М.М. Іжа та ін. Київ : НАДУ. 2014. $52 \mathrm{c}$.

\section{References:}

1. Bezverniuk T. (2010) Resursnyj rezhym jak instytucijnyj mehanizm resursnogo zabezpechennja regionalnogo upravlinnja [Resource regime as an institutional mechanism of regional government resource provision]. State building: electron. of sciences. profession. view. HARRY NAD. Available at: http://www.kbuapa.kharkov.ua (accessed 13.10.2019)

2. Kraynyk O.P. (2014) Osoblyvosti suchasnykh pidkhodiv do upravlinnya rehional'nym ekonomichnym rozvytkom [Peculiarities of contemporary approaches to the management of regional economic development]. Efficiency of Public Administration. Vol. 39 (pp. 419-419). Lviv: Lviv Regional Institute of Public Administration of NAPA.

3. Pidlisna O. A. (2007). Stan ta perspektyvy rozvytku rehioniv Ukrayiny: metody otsinky efektyvnosti terytorialnykh utvoren [Status and prospects of Ukraine's regions: the methods of evaluating the effectiveness of territorial units]. Regional Economy, 1(43), 104-116.

4. Izha M.M., Beregoy T.A., Popov S.A. (2014) Resursne zabezpechennja systemy regionalnogo upravlinnja: nauk. rozrobka [Resource Support for the Regional Management System: Sciences. Development]. K.: NADU (in Ukrainian) 


\section{РОЛЬ РЕСУРСНОГО ОБЕСПЕЧЕНИЯ В ПРОГНОЗИРОВАНИИ СОЦИАЛЬНО-ЭКОНОМИЧЕСКОГО РАЗВИТИЯ РЕГИОНА}

В статье исследована роль ресурсного обеспечения в прогнозировании социиально-экономического развития региона. Определено, что прогнозирование сочиально-экономического развития региона является процессом формирования научного обоснованного суждения о возможном состоянии исследуемых объектов. В работе исследованы функиии управления сочиально-экономическими проиессами и проанализированы место и роль прогнозирования в данном проиессе. Рассмотрены подходы, которые дают представление о предметной области регионального сочиально-экономического прогнозирования. На основе всестороннего анализа теорий регионального развития, а также кониепиий формирования и использования ресурсов региона предоставлено авторское определение ресурсного обеспечения соииально-экономического развития региона. Доказано, что от ресурсного обеспечения региона зависит развитие многих сфер его жизни, на основе этих данных строится управление территорией, разрабатываются иелевые программы, стратегии, от них в какой-то степени зависят безопасность населения и эволючия экономического сектора, поэтому в статье построена структурная схема, отражающая ресурсное обеспечение сочиально-экономического развития региона.

Ключевые слова: регион, ресурсное обеспечение, прогнозирование, сочиильно-экономическое развитие, региональное управление.

\section{THE ROLE OF RESOURCES SUPPLY IN THE FORECAST OF SOCIO-ECONOMIC DEVELOPMENT OF THE REGION}

The system of regional management of the processes of socio-economic growth is impossible without forecasting, which plays a leading role as a link among other important elements that implement the preparation of relevant decisions. For a regional system to make mistakes in the choice of management decisions, means to become the reason for the degradation of its development. To counteract such effects, it is necessary to remove some of the resources that provide economic development and social security for the region's citizens. The role of resource provision in forecasting the socio-economic development of a region is explored in the article. It has been determined that forecasting the socioeconomic development of a region is a process of forming a scientifically sound judgment about the possible state of the objects being studied. The functions of management of socio-economic processes are investigated and the place and role of forecasting in this process are analyzed. Approaches that give an idea of the subject area of regional socio-economic forecasting are considered. On the basis of a comprehensive analysis of the theories of regional development, as well as the concepts of formation and use of the resources of the region, the author's definition of the resource provision for the socio-economic development of the region is provided. It is proved that the development of many spheres of its life depends on the resource provision of the region, on the basis of these data the territory management is being developed, targeted programs, strategies are being developed, on which the security of the population and the evolution of the economic sector depend on them, so the article builds a structural diagram that reflects resource provision of socio-economic development of the region. Based on a comprehensive analysis of the theories of regional development, as well as the concepts of formation and use of resources of the region, we clarify the concept of resource provision of socio-economic development of the region. This concept is defined by us as a complex economic category, integrating the resources of the territory, being in a market economy is interrelated with internal and external socio-economic, environmental and management factors, and thus determines the development of the region.

Key words: region, resource support, forecasting, socio-economic development, regional governance. 